\title{
Standardization of milk using cold ultrafiltration retentates for the manufacture of Swiss cheese: Effect of altering coagulation conditions on yield and cheese quality
}

\author{
S. Govindasamy-Lucey, ${ }^{* 1}$ J. J. Jaeggi, ${ }^{*}$ C. Martinelli, ${ }^{*}$ M. E. Johnson, ${ }^{\star}$ and J. A. Lucey $†$ \\ *Wisconsin Center for Dairy Research and \\ †Department of Food Science, University of Wisconsin-Madison, Madison 53706
}

\begin{abstract}
Fortification of cheesemilk with membrane retentates is often practiced by cheesemakers to increase yield. However, the higher casein $(\mathrm{CN})$ content can alter coagulation characteristics, which may affect cheese yield and quality. The objective of this study was to evaluate the effect of using ultrafiltration (UF) retentates that were processed at low temperatures on the properties of Swiss cheese. Because of the faster clotting observed with fortified milks, we also investigated the effects of altering the coagulation conditions by reducing the renneting temperature (from 32.2 to $28.3^{\circ} \mathrm{C}$ ) and allowing a longer renneting time before cutting (i.e., giving an extra $5 \mathrm{~min}$ ). Milks with elevated total solids (TS; $\sim 13.4 \%$ ) were made by blending whole milk retentates $(26.5 \% \mathrm{TS}, 7.7 \% \mathrm{CN}, 11.5 \%$ fat $)$ obtained by cold $\left(<7^{\circ} \mathrm{C}\right)$ UF with part skim milk $(11.4 \% \mathrm{TS}$, $2.5 \% \mathrm{CN}, 2.6 \%$ fat) to obtain milk with CN:fat ratio of approximately 0.87 . Control cheeses were made from part-skim milk (11.5\% TS, $2.5 \% \mathrm{CN}, 2.8 \%$ fat). Three types of UF fortified cheeses were manufactured by altering the renneting temperature and renneting time: high renneting temperature $=32.2^{\circ} \mathrm{C}(\mathrm{UFHT})$, low renneting temperature $=28.3^{\circ} \mathrm{C}$ (UFLT), and a low renneting temperature $\left(28.3^{\circ} \mathrm{C}\right)$ plus longer cutting time ( +5 min compared to UFLT; UFLTL). Cutting times, as selected by a Wisconsin licensed cheesemaker, were approximately $21,31,35$, and 32 min for UFHT, UFLT, UFLTL, and control milks, respectively. Storage moduli of gels at cutting were lower for the UFHT and UFLT samples compared with UFLTL or control. Yield stress values of gels from the UF-fortified milks were higher than those of control milks, and decreasing the renneting temperature reduced the yield stress values. Increasing the cutting time for the gels made from the UF-fortified milks resulted in an increase in yield stress values. Yield strain values were significantly lower in gels made from control or UFLTL
\end{abstract}

Received September 20, 2010.

Accepted February 4, 2011.

${ }^{1}$ Corresponding author: rani@cdr.wisc.edu milks compared with gels made from UFHT or UFLT milks. Cheese composition did not differ except for fat content, which was lower in the control compared with the UF-fortified cheeses. No residual lactose or galactose remained in the cheeses after 2 mo of ripening. Fat recoveries were similar in control, UFHT, and UFLTL but lower in UFLT cheeses. Significantly higher $\mathrm{N}$ recoveries were obtained in the UF-fortified cheeses compared with control cheese. Because of higher fat and $\mathrm{CN}$ contents, cheese yield was significantly higher in UF-fortified cheeses ( 11.0 to $11.2 \%)$ compared with control cheese $(\sim 8.5 \%)$. A significant reduction was observed in volume of whey produced from cheese made from UF-fortified milk and in these wheys, the protein was a higher proportion of the solids. During ripening, the $\mathrm{pH}$ values and $12 \%$ trichloroacetic acid-soluble $\mathrm{N}$ levels were similar for all cheeses. No differences were observed in the sensory properties of the cheeses. The use of UF retentates improved cheese yield with no significant effect on ripening or sensory quality. The faster coagulation and gel firming can be decreased by altering the renneting conditions.

Key words: Swiss cheese, ultrafiltration, cheese yield, rennet coagulation

\section{INTRODUCTION}

Milk for Swiss cheese manufacture is usually standardized to a CN:fat ratio of approximately 0.85 by cream removal, which reduces the fat and CN contents of milk and thus decreases cheese yield. Milk for Swiss cheese manufacture can also be standardized with condensed milk or rehydrated NDM. However, the use of condensed milk or NDM can increase the residual lactose content of cheese. Another concern with the use of condensed milk or NDM for Swiss cheese manufacture is poor eye quality. In the United States, UF milks produced on large farms (Fassbender, 2001) are currently being used in the manufacture of Swiss cheese. The FDA approved the use of cold $\left(<7^{\circ} \mathrm{C}\right)$ UF of milk for use in Swiss cheese manufacture (CFR, 2005). However, the FDA indicated that the use of outsourced liquid UF retentates (i.e., UF milk purchased from a supplier or 
UF milk filtered by a cheese manufacturer at an offsite facility owned by the same manufacturer) should be declared on the ingredient statement for Swiss cheese.

In previous work (Govindasamy-Lucey et al., 2004, 2005), we reported that the use of cold UF retentates to fortify cheesemilks for the manufacture of Parmesan and stirred-curd pizza cheese required only slight modification of the manufacturing protocol so as to maintain a similar composition, quality, and functionality as the cheeses made from unfortified milk. The manufacturing modifications we investigated included the addition of starter, rennet, and salt on a TS or CN basis rather than on the volume of milk in the vat, as well as cutting the gels from the UF-fortified milks sooner. The rate of gel firming is faster in UF-fortified milk; therefore, in commercial cheese plants the coagulation process must be carefully monitored to initiate cutting sooner than would be done for gels made from unconcentrated milk. Otherwise, gels become excessively firm and high fat losses may occur during cutting. Previous work (Guinee et al., 1994) showed that increasing the milk protein levels from 3.0 to $8.2 \%$ by fortifying Cheddar cheesemilks with warm skim UF retentates resulted in increased rate of gel firming and a decrease in the time between rennet addition and cutting (when cutting at equal firmness). In practice, in milks with higher protein levels $(>4.0 \%)$, the cutting process becomes more difficult because of short gelation times and very rapid gel firming rates (Sutherland and Jameson, 1981; Guinee et al., 1994).

Many cheese plants are currently fortifying cheesemilks with milk solids to increase yield and improve processing efficiency. Homogenization or use of lower renneting temperature for UF milk resulted in improved fat retention (Green et al., 1983; Green, 1985, 1987). The increased fat recovered in cheeses made with homogenized UF milks is due to the presence of $\mathrm{CN}$ on the fat membrane surface causing better association with the $\mathrm{CN}$ gel matrix. The rate of protein aggregation in cheesemilks with higher $\mathrm{CN}$ contents can be reduced by performing the renneting process at a lower temperature. For UF-fortified milks, a small decrease in renneting temperature from 32 to $27^{\circ} \mathrm{C}$ and a reduction in the concentration of rennet used for Cheddar cheese manufacture decreased the gel firming rate and increased the time between rennet addition and cutting closer to that observed for the control milk, which helped to reduce fat losses in whey (Guinee et al., 1994). However, decreasing the concentration of rennet used for cheesemaking resulted in lower rates of proteolysis in cheeses made from milks fortified with UF retentates (Green et al., 1981; Green, 1985; Creamer et al., 1987; Spangler et al., 1990; Guinee et al., 1994).
The objective of this study was to investigate the effect of using cold whole milk UF retentates to fortify cheesemilks for Swiss cheese manufacture. We also wanted to determine the effect of altering coagulation conditions on rennet coagulation properties, cheese yield, composition, and proteolysis. The same rennet:CN ratio was used for the control and the UF-fortified cheesemilks to try to ensure similar levels of proteolysis in all Swiss cheeses.

\section{MATERIALS AND METHODS}

\section{Ultrafiltration and Standardization of Milk}

Raw whole milk was obtained from the University of Wisconsin-Madison dairy plant on the day before cheesemaking. Low-concentration-factor UF was performed on whole milk to approximately $27 \%$ TS $(7.8 \% \mathrm{CN})$. The low-concentration-factor UF was performed at less than $7^{\circ} \mathrm{C}$, by recirculation through a UF unit (APV Americas, Tonawanda, NY) fitted with 2 spiral-wound, polyethersulfone membranes (each with a molecular weight cut-off of 10,000 Da and membrane area of 5.57 $\mathrm{m}^{2}$, PTI Advanced Filtration, Oxnard, CA) that were modified by Membrane Systems Specialists (Wisconsin Rapids, WI). During the UF process, milk was cooled in a spiral tubing system that was submerged in a chilled $\left(\sim 4^{\circ} \mathrm{C}\right)$ water tank to maintain the low temperatures that would be required if the cold UF process $\left(<7^{\circ} \mathrm{C}\right)$ were performed on-farm. The retentates were then stored overnight at $4^{\circ} \mathrm{C}$ and blended to the specified $\mathrm{CN}$ :fat ratio the following morning to give standardized cheesemilks.

Two types of cheesemilks were prepared: control and milk fortified with whole milk UF retentate. A mean $\mathrm{CN}$ :fat ratio of 0.89 was achieved in the control cheesemilk by cream removal to obtain part-skim milk with $2.51 \% \mathrm{CN}$ and $2.79 \%$ fat (Table 2). The UF retentatefortified cheesemilks were prepared by blending whole milk UF retentate ( $15 \%$ on a weight basis; Table 1$)$ with part-skim milk $(2.56 \%$ fat, $2.54 \% \mathrm{CN})$ to obtain milks with $13.35 \%$ TS $(\sim 3.28 \% \mathrm{CN})$ and a mean $\mathrm{CN}$ :fat ratio of 0.87 (Table 2). Control cheese was manufactured using a renneting temperature of $32.2^{\circ} \mathrm{C}$. Three types of UF-fortified cheeses were manufactured. The first used a similar manufacturing protocol as the control milk; that is, a high renneting temperature $\left(32.2^{\circ} \mathrm{C}\right.$; UFHT); the second used a low renneting temperature $\left(28.3^{\circ} \mathrm{C}\right.$; UFLT); and the third used a low renneting temperature $\left(28.3^{\circ} \mathrm{C}\right)$ and the time before starting cutting was extended by 5 min compared with that used for UFLT milk (to allow the gel to become firmer; UFLTL). The lower renneting temperature $\left(28.3^{\circ} \mathrm{C}\right)$ was selected 
Table 1. Average weights and composition of the milk and retentates used in the preparation of the UF-fortified cheesemilks $(\mathrm{n}=2)$

\begin{tabular}{|c|c|c|c|c|c|}
\hline Treatment & $\begin{array}{l}\text { Weight of milk/UF } \\
\text { retentate used } \\
\text { in blending }(\%)\end{array}$ & $\begin{array}{l}\text { TS } \\
(\%)\end{array}$ & $\begin{array}{l}\mathrm{CN} \\
(\%)\end{array}$ & $\begin{array}{c}\text { Total } \\
\text { protein }(\%)\end{array}$ & $\begin{array}{c}\text { Milk } \\
\text { fat }(\%)\end{array}$ \\
\hline \multicolumn{6}{|c|}{$\begin{array}{l}\text { UFHT, UFLT, and UFLTL milks }{ }^{1} \\
\text { were prepared by blending: }\end{array}$} \\
\hline (a) UF retentate & $14.9 \pm 1.4$ & $26.52 \pm 0.18$ & $7.73 \pm 0.26$ & $9.62 \pm 0.33$ & $11.50 \pm 0.08$ \\
\hline (b) Part skim milk & $85.1 \pm 2.4$ & $11.41 \pm 0.12$ & $2.54 \pm 0.04$ & $3.26 \pm 0.09$ & $2.56 \pm 0.00$ \\
\hline
\end{tabular}

${ }^{1} \mathrm{UFHT}=$ cheeses made from UF-fortified cheesemilks using a high renneting temperature of $32.2^{\circ} \mathrm{C}$; UFLT $=$ cheeses made from UF-fortified cheesemilks using a low renneting temperature of $28.3^{\circ} \mathrm{C}$; UFLTL $=$ cheeses made from UF-fortified cheesemilks using a low renneting temperature of $28.3^{\circ} \mathrm{C}$ and a longer cutting time of $5 \mathrm{~min}$.

based on preliminary trials carried out using dynamic oscillatory rheology as described by GovindasamyLucey et al. (2004). The lower renneting temperature used for UFLT milks resulted in these gels having the same storage modulus $\left(\mathbf{G}^{\prime}\right)$ value at cutting as those made from the control milk.

\section{Cheese Manufacture and Sampling Procedures}

The day after membrane processing, 8 vats of Swiss cheese were manufactured by a Wisconsin licensed cheesemaker in the University of Wisconsin-Madison dairy processing pilot plant using a traditional Swiss cheese manufacturing protocol. Four types of cheeses were manufactured, as described in the previous section. Each trial involved the manufacture of duplicate cheese treatments. Cheesemaking trials were replicated twice on different days starting with 2 different batches of whole milk UF retentates; the order of vats was randomized. Prior to cheesemaking, blended milks were heat-treated at $66.7^{\circ} \mathrm{C}$ for $19 \mathrm{~s}$ and cooled to $5^{\circ} \mathrm{C}$. Milk for each individual vat was sampled for chemical analysis and then weighed on a floor scale (model 311822-FD, Toledo Scale Co., Toledo, OH) before being gravity-fed into each individual vat. The control vats were filled with $227 \mathrm{~kg}$ of heat-treated milks. In the experimental vats (UF-fortified milks), only $170 \mathrm{~kg}$ of standardized milk was used. This resulted in all vats producing similar weights of curd. In all experimental vats, the weight of milk used in the vat was based on having a similar $\mathrm{CN}$ content compared with the control vat. The milk temperature was then increased to the renneting temperatures of $32.2,32.2,28.3$, and $28.3^{\circ} \mathrm{C}$ for control, UFHT, UFLT, and UFLTL vats, respectively. The starter cultures used were direct-to-vat set culture comprising Streptococcus thermophilus strains (DVS TD-17, Cargill Texturizing Solutions, Waukesha, WI) and Lactobacillus helveticus (DVS LH32, Chr. Hansen, Inc., Milwaukee, WI). The amount of starters added to all vats was based on the $\mathrm{CN}$ concentration of the cheesemilks $(2.32 \pm 0.07 \mathrm{~g}$ of TD-17/ $\mathrm{kg}$ of $\mathrm{CN}$ and $893 \pm 27 \mathrm{mg}$ of $\mathrm{LH} 32 / \mathrm{kg}$ of $\mathrm{CN})$. In addition, a direct- to-vat Propionibacterium freudenreichii ssp. shermanii (PS-1, Chr. Hansen, Inc.) was added to the control and experimental milks at the rate of $268 \pm 8 \mu \mathrm{L}$ per $\mathrm{kg}$ of CN. In addition, RL3, a wild-strain of Lactobacillus isolated from mature Cheddar cheese at the Wisconsin Center for Dairy Research, was used as an adjunct culture. Lactobacillus plantarum RL3 is a natural isolate that has been suggested to produce succinate when present in cheese during the ripening process (Dikkeboom, 1999). When grown in de Man, Rogosa, and Sharpe broth, this strain is able to produce high succinic acid levels (Dudley and Steele, 2005). This culture was grown for $24 \mathrm{~h}$ in de Man, Rogosa, and Sharpe broth at $32^{\circ} \mathrm{C}(\mathrm{pH} 4.6)$ and was then added to both the control and experimental vats at the rate of 17.86 $\pm 0.59 \mathrm{~mL}$ per $\mathrm{kg}$ of $\mathrm{CN}$. Following a 30-min ripening period, double-strength chymosin (Chymostar, Danisco USA, Inc., Madison, WI) was added to the control and experimental milks at a rate of 75 and $100 \mu \mathrm{L}$ per $\mathrm{kg}$ of milk, respectively. The amount of rennet added to each vat was also based on total $\mathrm{CN}$ concentration (3.04 \pm $0.09 \mathrm{~mL}$ per $\mathrm{kg}$ of $\mathrm{CN}$ ).

The coagula were cut at similar firmness as evaluated subjectively by an experienced, licensed Wisconsin cheesemaker. The coagulum was cut with 6 -mm knives at $\mathrm{pH} 6.61 \pm 0.03$. The temperature of the cheese vat was raised to the cooking temperature of $50^{\circ} \mathrm{C}$ over a 40-min period. During this heating period, $14.76 \mathrm{~kg}$ of water at $37.8^{\circ} \mathrm{C}$ was added to each of the vats. After the vats reached the cooking temperature, another $14.76 \mathrm{~kg}$ of water at $43.3^{\circ} \mathrm{C}$ was added, which reduced the slurry temperature to $48.3^{\circ} \mathrm{C}$. After a 40 -min hold time to allow the curd $\mathrm{pH}$ to decrease to approximately 6.30 , agitation was stopped, and $36.32 \mathrm{~kg}$ of whey was predrawn and pumped from each vat into a separate pressing vat (Stoelting, Kiel, WI). The remainder of the curd and whey mixture was then pumped into the pressing vat over a 10-min period. A perforated lid was placed on the top of the curd-whey mixture and $206 \mathrm{kPa}$ pressure applied over a 25-min period. After pressing, the whey was drained, weighed on a floor scale (model 8140, Toledo Scale Co.), and sampled. The cheese blocks were 
Table 2. Composition of cheesemilk, drain whey, press whey, and cheese $(\mathrm{n}=4)$

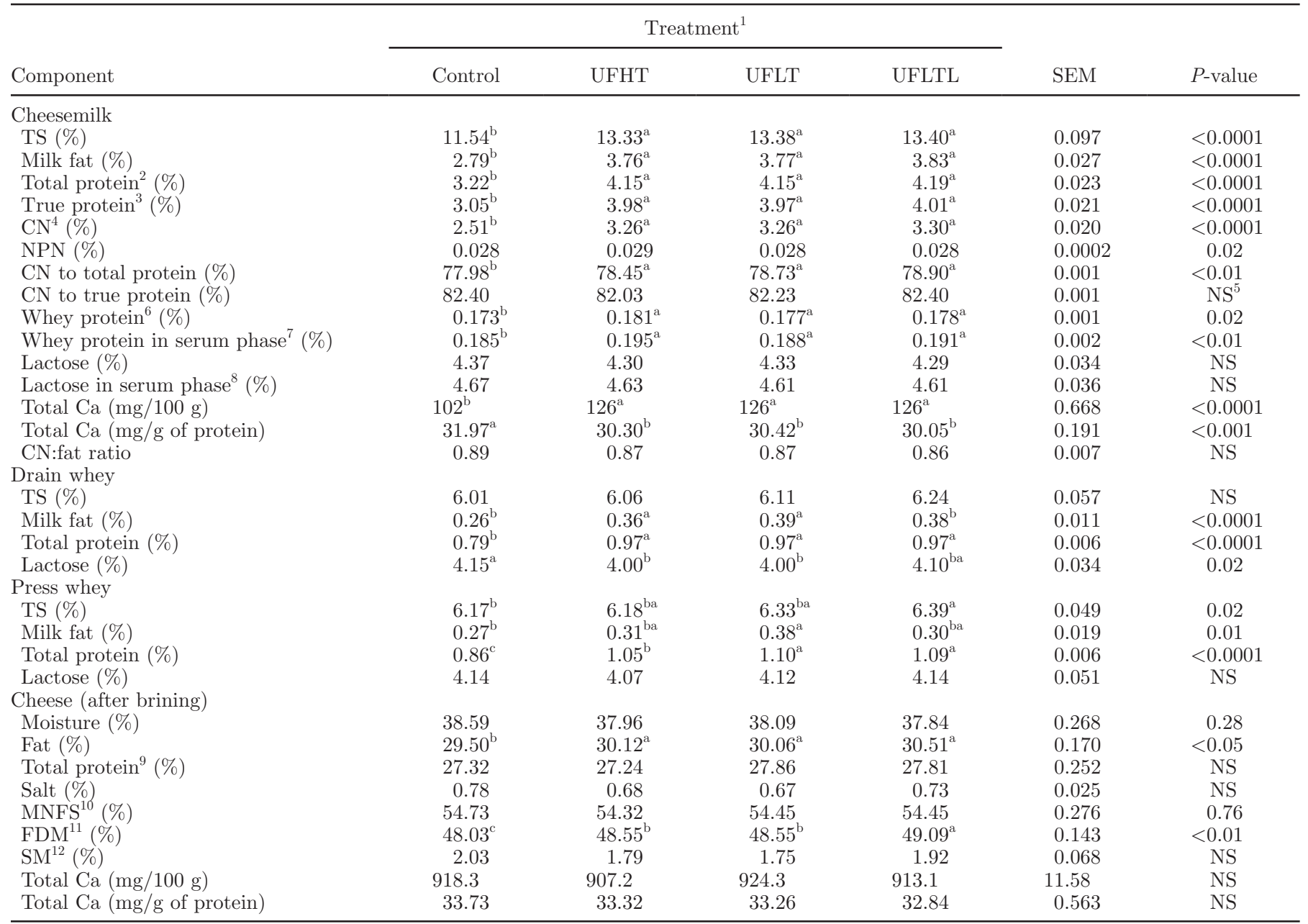

${ }^{\mathrm{a}-\mathrm{c}}$ Means within the same row not sharing a common superscript differ $(P<0.05)$.

${ }^{1} \mathrm{UFHT}=$ cheeses made from UF-fortified cheesemilks using a high renneting temperature of $32.2^{\circ} \mathrm{C}$; UFLT $=$ cheeses made from UF-fortified cheesemilks using a low renneting temperature of $28.3^{\circ} \mathrm{C}$; UFLTL $=$ cheeses made from UF-fortified cheesemilks using a low renneting temperature of $28.3^{\circ} \mathrm{C}$ and a longer cutting time of $5 \mathrm{~min}$.

${ }^{2}$ Total $\% \mathrm{~N} \times 6.35$.

${ }^{3}($ Total $\% \mathrm{~N}-\% \mathrm{NPN}) \times 6.35$.

${ }^{4}($ Total $\% \mathrm{~N}-\%$ noncasein $\mathrm{N}) \times 6.36$.

${ }^{5}$ Nonsignificant ( $F$-test for full statistical model $\left.P>0.05\right)$.

${ }^{6}$ True protein $-\mathrm{CN}$.

${ }^{7}$ Whey protein in serum phase $=\%$ whey protein $/(100 \%-\%$ fat $-\% \mathrm{CN})$.

${ }^{8}$ Lactose in serum phase $=\%$ lactose $/(100 \%-\%$ fat $-\% \mathrm{CN})$.

${ }^{9}$ Total $\% \mathrm{~N} \times 6.31$.

${ }^{10}$ Moisture in the nonfat substance of the cheese.

${ }^{11}$ Fat content on a dry weight basis.

${ }^{12}$ Salt in the moisture phase of the cheese.

removed, cut in half, packed into 9-kg Wilson hoops, and pressed in a horizontal cheese press at $206 \mathrm{kPa}$ for $4 \mathrm{~h}$ at approximately $23^{\circ} \mathrm{C}$. Press whey was collected, weighed (model MSG-500 Series Electronic Scales, Mars Scale Group, Niagara Falls, NY), and sampled. After pressing, the cheeses were placed in a warm room $\left(21^{\circ} \mathrm{C}\right)$ overnight to ensure that all the sugars (lactose/galactose) were fermented by the end of $1 \mathrm{~d}$. The following morning, the cheeses were removed from the molds and weighed (model CW-80I-2A, Rice Lake Weighing Systems, Rice Lake, WI). Following brining for approximately $12 \mathrm{~h}$ at 3 to $5^{\circ} \mathrm{C}$, the cheeses were weighed again. The cheeses were vacuum-packaged in Cryovac standard clear bags (9Fv86, Cryovac North 
America, Duncan, SC) and aged at $7^{\circ} \mathrm{C}$ for $7 \mathrm{~d}$. The cheeses were then moved to the warm room and stored at $23^{\circ} \mathrm{C}$ for 4 wk. Following removal from the warm room, cheeses were ripened at $7^{\circ} \mathrm{C}$ for 9 mo.

\section{Compositional Analyses of Milks, Wheys, and Cheeses}

All compositional analyses were carried out in triplicate. Milk, drain whey, and press whey samples were analyzed for fat by Mojonnier (AOAC, 2000), protein (total percentage $\mathrm{N} \times 6.35$ ) by Kjeldahl $(\mathrm{AOAC}, 2000$ ), CN (AOAC, 2000), lactose (AOAC, 2000), TS (Green and Park, 1980), and NPN (AOAC, 2000).

The cheeses were sampled for compositional analysis at $60 \mathrm{~d}$. At the time of sampling, a quarter of the block was cut off and half of this quarter was completely ground and used for analysis. Cheese samples were analyzed for moisture (Marshall, 1992), fat (AOAC, 2000), protein by Kjeldahl (AOAC, 2000), salt by the chloride electrode method (model 926, Corning Glass Works, Medfield, MA; Johnson and Olson, 1985). Lactose/ galactose contents (Boehringer Mannheim, 1997) in the cheeses were analyzed at $60 \mathrm{~d}$. $\mathrm{pH}$ of the cheeses were analyzed by the quinhydrone method (Marshall, 1992) at 1 (after brining), 60, 180, and $270 \mathrm{~d}$. Proteolysis was monitored during ripening by measuring the amount of $12 \%$ TCA-soluble nitrogen at $60,120,180$, and $270 \mathrm{~d}$ (AOAC, 2000).

\section{Fat, Nitrogen, and TS Recoveries and Cheese Yield}

A mass balance was carried out for each vat of cheese. Milk and drain whey were weighed to $\pm 0.1 \mathrm{~kg}$ (milk, model 31-1822-FD; drain whey, model 8140, Toledo Scale Co.), press whey was weighed to $\pm 0.1 \mathrm{~kg}$ (model MSG-500 Series Electronic Scales, Mars Scale Group), and cheese was weighed to $\pm 0.01 \mathrm{~kg}$ (model CW-80I2A, Rice Lake Weighing Systems). The percentage of fat, N, or TS recovered in the cheese, drain whey, and press whey was calculated as the total amount of fat, $\mathrm{N}$, or TS in the each one of these products divided by the total amount of fat, $\mathrm{N}$, or TS in the original cheesemilk, multiplied by 100 .

Actual yield was calculated for each vat of cheese as the weight of cheese divided by the weight of the original cheese milk (including the amount of cultures added during cheese manufacture), multiplied by 100 . Actual cheese yield was adjusted to the target cheese moisture content (for Swiss, this was 38\%) to eliminate the effects of moisture variations among treatments on the yield calculations. The approach described by Govindasamy-Lucey et al. (2006) was used to determine the predictive cheese yield, and the recoveries of fat, CN, and other solids in cheese. Predictive cheese yields were calculated for each vat using the Van Slyke cheese yield equation [1], as shown below (Van Slyke and Price, 1936):

$$
\begin{aligned}
& \text { Van Slyke cheese yield }= \\
& \frac{[(R F \times \% \text { fat in milk })+(R C \times \% \text { casein in milk })] \times R S}{(100-\% \text { moisture of cheese })},
\end{aligned}
$$

where $R F$ is fraction of fat recovered in cheese, $R C$ is fraction of $\mathrm{CN}$ recovered in cheese, and $R S$ reflects the proportion of other milk solids and salt recovered in cheese in relation to the amount of $\mathrm{CN}$ and fat in cheese. The $R F$ values were determined experimentally as fat recovery for each cheese type obtained from the cheesemaking trials. Both $R C$ and $R S$ were calculated according to the method described by GovindasamyLucey et al. (2006).

\section{Rheological Properties During the Rennet Coagulation of Cheesemilks}

Rennet-induced milk gels are viscoelastic and their small deformation rheological properties can be determined by dynamic low-amplitude oscillatory rheometry by measuring $\mathrm{G}^{\prime}$, loss modulus, and loss tangent ( $\mathrm{Lu}-$ cey, 2002). The rheological characteristics of cheesemilks during renneting were measured at either 32.2 or $28.3 \pm 0.1^{\circ} \mathrm{C}$. A UDS 200 Physica rheometer (Physica Messtechnik, Stuttgart, Germany), operating in oscillation mode at a frequency of $0.1 \mathrm{~Hz}$ and a strain of $1 \%$, was used to measure the rheological parameters. The measuring system consisted of 2 coaxial cylinders (diameters 25.0 and $27.5 \mathrm{~mm}$ ). A profiled (serrated) bob was used in this couette-type fixture. The same concentration of starter cultures and rennet used in cheesemaking trials were also used in coagulation experiments. Samples of cheesemilks were taken from each vat (before the addition of starter or rennet) and all milk samples were stored at $4^{\circ} \mathrm{C}$. Prior to testing, milk samples (50 $\mathrm{g}$ and $37.5 \mathrm{~g}$ of control and UF-fortified milks, respectively) were warmed to the coagulation temperature for about $30 \mathrm{~min}$ in a waterbath and then inoculated with the starters $(2.90 \mathrm{mg}$ of TD-17 and $1.10 \mathrm{mg}$ of LH32). Thirty minutes later, $100 \mu \mathrm{L}$ of distilled water containing $3.74 \mu \mathrm{L}$ of double-strength chymosin (Chymostar, Danisco USA, Inc.), was added to the milks and mixed thoroughly; approximately 13 $\mathrm{mL}$ of the mixture was immediately placed in the cup (maintained at 32.2 or $28.3^{\circ} \mathrm{C}$ ) of the rheometer. Vegetable oil was layered onto the surface of the milk to prevent evaporation. Measurements were started $120 \mathrm{~s}$ 
after rennet addition and measurements were recorded at 60 -s intervals until the time when the cheesemaker decided to cut the gels. This cutting time varied for each of the milk samples. Gelation time was defined as the point when gels had a $\mathrm{G}^{\prime} \geq 0.1 \mathrm{~Pa}$ (i.e., when $\mathrm{G}^{\prime}$ values became greater than noise level).

To determine the resistance of the coagulum to cutting, we studied the large deformation properties of the rennet gels using the constant shear rate technique for determining an apparent yield stress and shear deformation at yielding as described previously (Govindasamy-Lucey et al., 2004). Gels were made in situ as described above and sheared at a constant shear rate of approximately $0.01 \mathrm{~s}^{-1}$ at 32.2 or $28.3^{\circ} \mathrm{C}$; shearing was initiated at the cutting time specified by our cheesemaker for that milk type. Gels were subjected to constant shear rate up to yielding of the gel, which was defined as the point when the shear stress started to decrease (Lucey et al., 1997a).

\section{Experimental Design and Statistical Analysis}

Two replicate cheesemaking trials were carried out; in each trial, 2 standardized milks (i.e., control and milks fortified with whole milk UF retentate) were used to make Swiss cheese. A $4 \times 2$ completely randomized block design, which incorporated all 4 treatments in duplicate and 2 blocks (replicate trials), were used for analysis of the response variables relating to milk, cheese, and whey composition, and coagulation properties. Analysis of variance was carried out using the PROC GLM procedure of SAS (version 9.1; SAS Institute, 2002-2003). In the ANOVA model, all 4 different treatments were analyzed as a discontinuous variable, whereas cheesemaking day (i.e., different batches of milk) was blocked. Scheffé's multiple-comparison test was carried out to evaluate differences in the treatments means at a significance level of $P<0.05$.

A split-plot design was used to monitor the effects of treatment and time of aging and their interactions on $\mathrm{pH}$ and proteolysis (12\% TCA-soluble $\mathrm{N}$ expressed as a percentage of total $\mathrm{N}$ ). In the whole plot factor, treatment was analyzed as a discontinuous variable, whereas cheesemaking day was blocked. For the subplot factor analysis, age and the quadratic form of age (age $\times$ age) were treated as continuous variables. The interactive term treatment $\times$ cheesemaking day was treated as the error term for the treatment effect. The ANOVA for the split plot design was carried out using PROC GLM of SAS.

\section{Sensory Analysis}

Sensory assessment was carried out at 2, 4, 6, and 9 mo by 2 licensed Wisconsin cheese graders who have judged Swiss cheeses in both national and international contests. Judges, on a consensus basis, evaluated the cheeses for flavor defects, body and texture defects, appearance defects, and color defects. Random numbers were assigned to the cheeses.

\section{RESULTS AND DISCUSSION}

\section{Composition of UF Retentates and Cheesemilks}

The total protein, fat, TS, and CN contents of the UF retentates were $9.62,11.50,26.52$, and $7.73 \%$, respectively (Table 1). As expected, the TS, fat, total protein, true protein, and $\mathrm{CN}$ contents were significantly $(P<$ 0.05) higher in the milks fortified with UF retentates (UFHT, UFLT, and UFLTL) than in the control milks (Table 2). Both lactose contents and lactose levels in the serum phase (lactose $/ 100-\%$ fat $-\% \mathrm{CN}$ ) of the control and the UF-fortified milks were similar (Table 2 ). Whey protein contents, as well as the whey protein in the serum phase, were lower in the control milks than in the UF-fortified milks (Table 2). The total calcium content was higher in the UF-fortified cheesemilks compared with control milk, probably due to higher $\mathrm{CN}$ content in the fortified cheesemilks. All milks were standardized to similar CN:fat ratio, 0.86 to 0.89 , within the range expected for Swiss cheese (Table 2).

\section{Cheese Composition}

Although not significantly different $(P>0.05)$, the moisture contents of all UF-fortified cheeses were slightly lower than those of the control cheeses (Table 2). Fat content in the UF-fortified cheeses was slightly higher than in the control cheeses (Table 2). The slightly lower moisture contents of the UF-fortified cheeses (although not significantly different) and a slightly lower CN:fat ratio in the UF cheesemilks (not significantly different) may have contributed to the observed differences in cheese fat contents. The total protein and salt contents of the cheeses were similar. The fat in DM of the UFfortified cheeses was higher than that of the control cheeses but was within the typical range of values (0.48-0.49) expected for Swiss cheese. The other compositional parameters were not significantly different between treatments. No residual lactose or galactose remained in any of the cheeses after 2 mo of ripening (results not shown).

\section{Coagulation Properties}

The rheological properties of the rennet-induced cheesemilk gels are shown in Table 3. The gelation time, as determined by the rheometer, was significantly 
Table 3. Effects of higher solids on the rheological properties of rennet-induced cheesemilk gels $(\mathrm{n}=4)$

\begin{tabular}{|c|c|c|c|c|c|c|}
\hline Item & \multicolumn{4}{|c|}{ Treatment $^{1}$} & SEM & $P$-value \\
\hline $\begin{array}{l}\text { Gelation time }^{2}(\min ) \\
\text { Storage modulus }\left(\mathrm{G}^{\prime}\right) \text { at cutting }{ }^{3}(\mathrm{~Pa}) \\
\text { Cutting time } \\
\text { Yield } \operatorname{stress}^{5}(\mathrm{~Pa}) \\
{\text { Yield } \operatorname{strain}^{5}}^{5}\end{array}$ & $\begin{array}{r}27.10^{\mathrm{b}} \\
1.48^{\mathrm{a}} \\
31.70^{\mathrm{b}} \\
22.79^{\mathrm{c}} \\
2.74^{\mathrm{b}}\end{array}$ & $\begin{array}{r}19.55^{\mathrm{c}} \\
0.50^{\mathrm{b}} \\
20.79^{\mathrm{c}} \\
32.42^{\mathrm{a}} \\
3.78^{\mathrm{a}}\end{array}$ & $\begin{array}{r}29.98^{\mathrm{a}} \\
0.42^{\mathrm{b}} \\
30.67^{\mathrm{b}} \\
27.42^{\mathrm{b}} \\
3.60^{\mathrm{a}}\end{array}$ & $\begin{array}{r}30.79^{\mathrm{a}} \\
1.40^{\mathrm{a}} \\
35.23^{\mathrm{a}} \\
34.83^{\mathrm{a}} \\
2.90^{\mathrm{b}}\end{array}$ & $\begin{array}{l}0.615 \\
0.202 \\
0.605 \\
1.104 \\
0.183\end{array}$ & $\begin{array}{l}<0.0001 \\
<0.01 \\
<0.0001 \\
<0.0001 \\
<0.001\end{array}$ \\
\hline
\end{tabular}

$(P<0.01)$ shorter in the UFHT milk compared with the control milk when the renneting temperature for both samples was $32.2^{\circ} \mathrm{C}$. The shorter gelation time with the UFHT milk was presumably due to its higher $\mathrm{CN}$ content and because rennet was added on a CN basis rather than a volume basis, gelation occurred faster (i.e., there was more substrate and more enzyme), in agreement with the results of Creamer et al. (1987). The cheesemakers cut the UFHT gels (20.8 min) faster than the control gels $(31.7 \mathrm{~min})$ based on their subjective assessment of firmness. However, they cut the UFHT cheesemilks when the gels were soft, as reflected by the significantly $(P<0.01)$ lower $\mathrm{G}^{\prime}$ values at cutting for the UFHT gels $(0.50 \mathrm{~Pa})$ compared with the control gels $(1.48 \mathrm{~Pa})$. From their prior cheesemaking experience, the cheesemakers were concerned about the very rapid rate of firming in UF-fortified milks so they initiated cutting as soon as a soft gel was formed. Reducing the renneting temperature for the UF-fortified milks from 32.2 (UFHT) to $28.3^{\circ} \mathrm{C}$ (UFLT) resulted in an increase in the gelation time from 19.6 to $30.0 \mathrm{~min}$, which was still slightly longer than the control milks (27.1 min). The UFLT gels were also cut soft as the $\mathrm{G}^{\prime}$ values at cutting were similar to those of the UFHT gels. By reducing the renneting temperature, cutting times became closer to those of the control milk (31.7 $\mathrm{min}$ ); these results were consistent with those of Guinee et al. (1994). However, the $\mathrm{G}^{\prime}$ values at cutting were higher for the UFLTL gels than for the UFHT or UFLT gels, but similar to those for the control milks. The observed increase in the $\mathrm{G}^{\prime}$ value at cutting for UFLTL gel was probably due to the UFLTL gel network having more time to stiffen (Mishra et al., 2005). Rearrangements of existing particles in the network result in more contact area between CN molecules (Walstra, 1993); it is also possible that the increased $\mathrm{G}^{\prime}$ value could be due to the incorporation of additional (newly renneted) casein micelles into the gel network (Zoon et al., 1988).

The yield stress value; that is, the force required to break the gel network, was higher for the UF-fortified milks (27-35 Pa) compared with gels made from the control milks (23 Pa; Table 3). The higher yield stress value for the UF-fortified milk was probably due to the higher CN content of the UF-fortified milks because CN is the structure-forming material in the gel matrix. The rapid rate of firming in gels made from higher solids milks could be another factor responsible for the higher yield stress values, as the gels kept increasing in firmness during the slow shear rate test used to determine the yield strain. For the UF-fortified milks, decreasing the renneting temperature resulted in lower yield stress values (Table 3). Mishra et al. (2005) reported that yield stress values increased when renneting temperature was increased from approximately 29 to $32.2^{\circ} \mathrm{C}$ for rennet-induced gels. Mishra et al. (2005) attributed the increased yield stress to an increased fusion of $\mathrm{CN}$ micelles at the higher temperature, which increased the strength and number of bonds in the gel matrix. A slightly longer cutting time for the UFLTL sample resulted in increased yield stress values, similar to those for UFHT but higher than those for UFLT milks, possibly due to more $\mathrm{CN}$ micelles being incorporated into the gel network with the longer time (Zoon et al., 1988).

Yield strain values were significantly $(P<0.01)$ lower in gels made from control milks relative to UFHT milks (Table 3), reflecting a shorter (more brittle) gel structure. Decreasing the renneting temperature did not result in a change in the yield strain of the UF-fortified milk gels. The yield strain values for the UF-fortified milk gels were lower when cutting time was increased. Mishra et al. (2005) reported that the shear strain values of rennet-induced milk gels decreased with aging 
time, presumably a consequence of rearrangements in the matrix (Lucey et al., 1997b). Thus, rennet-induced gels tend to become more brittle with time.

\section{Fat, N, and TS Recoveries}

The amounts of fat recovered in the UFHT and control cheeses were not different (Table 4). However, reducing the renneting temperature from 32.2 to $28.3^{\circ} \mathrm{C}$ for the UFLT cheese resulted in a decrease in the amount of fat recovered. For the UFLTL cheese, fat recovery improved when the coagulum was allowed to firm up for extra 5 min before cutting. Decreasing the renneting temperature results in a lower aggregation rate for renneted micelles (Dalgleish, 1982). The coagulum formed at the lower renneting temperature of $28.3^{\circ} \mathrm{C}$ was easier to cut (lower yield stress, Table 3 ) compared with gels formed at $32.2^{\circ} \mathrm{C}$ (Table 3). The rennet gel network strengthens with time and it becomes harder to remove moisture from the gel (Johnson et al., 2001), which might explain why delaying the cutting time reduced fat losses (Table 4).

The $\mathrm{N}$ recoveries in the UF-fortified cheeses were higher than those observed in the control cheeses (Table 4), irrespective of renneting temperature. Nitrogen recoveries did not differ among the UF-fortified cheeses. The increase in $\mathrm{N}$ recovery for UF-fortified cheeses was probably due to a higher proportion of $\mathrm{CN}$ to serum protein in higher TS milks relative to the control milks
(Table 2). Another possible explanation is that the gels made from UF-fortified milks could have been more resistant to shattering during cutting or stirring and thus have retained more $\mathrm{CN}$ during cheesemaking compared with gels from the control milk. Losses of $\mathrm{N}$ in the drain whey were significantly $(P<0.01)$ lower in the UF-fortified cheeses compared with control cheeses (Table 4).

A significantly $(P<0.01)$ higher recovery of TS was observed in the UF-fortified cheeses compared with the control cheeses (Table 4). This was expected because the UF-fortified cheeses were made from milks containing higher $\mathrm{CN}(\sim 5-7 \%$ of $\mathrm{CN}$ is lost in whey as $\mathrm{CN}$ macropeptide; Lucey and Kelly, 1994) and higher fat contents relative to control. Decreasing the renneting temperature or increasing the time allowed before cutting did not affect the amount of TS recovered in the UF-fortified cheeses, even though these factors affected the amount of fat recovered in cheese.

\section{Cheese Yield}

Actual and moisture-adjusted cheese yields (MACY) were higher in the UF-fortified cheeses than in the control cheeses (Table 5), due to higher $\mathrm{CN}$ and fat contents in these cheesemilks. Decreasing the renneting temperature used for the UF-fortified cheesemilks influenced the actual yield and MACY; both were slightly lower in UFLT cheeses than in UFHT cheeses (Table

Table 4. Fat, nitrogen, and solids recovery for Swiss cheeses $(\mathrm{n}=4)$

\begin{tabular}{|c|c|c|c|c|c|c|}
\hline \multirow{2}{*}{$\begin{array}{l}\text { Component } \\
\text { recovery }\end{array}$} & \multicolumn{4}{|c|}{ Treatment $^{1}$} & \multirow[b]{2}{*}{ SEM } & \multirow[b]{2}{*}{$P$-value } \\
\hline & Control & UFHT & UFLT & UFLTL & & \\
\hline \multicolumn{7}{|l|}{$\%$ Fat recovery } \\
\hline Cheese & $89.79^{\mathrm{a}}$ & $89.60^{\mathrm{a}}$ & $87.63^{\mathrm{b}}$ & $88.93^{\mathrm{a}}$ & 0.273 & $<0.01$ \\
\hline Drain whey & $9.74^{\mathrm{b}}$ & $10.07^{\mathrm{ba}}$ & $10.69^{\mathrm{a}}$ & $10.38^{\mathrm{ba}}$ & 0.208 & $<0.05$ \\
\hline Pressed whey & 0.041 & 0.046 & 0.055 & 0.057 & 0.005 & NS \\
\hline Total & 99.57 & 99.72 & 98.38 & 99.37 & & \\
\hline \multicolumn{7}{|c|}{$\%$ Nitrogen recovery } \\
\hline Cheese & $72.45^{\mathrm{b}}$ & $73.91^{\mathrm{a}}$ & $74.36^{\mathrm{a}}$ & $74.62^{\mathrm{a}}$ & 0.315 & $<0.01$ \\
\hline Drain whey & $25.24^{\mathrm{a}}$ & $24.26^{\mathrm{b}}$ & $24.34^{\mathrm{b}}$ & $24.06^{\mathrm{b}}$ & 0.143 & $<0.001$ \\
\hline Pressed whey & $0.11^{\mathrm{b}}$ & $0.14^{\mathrm{b}}$ & $0.15^{\mathrm{ba}}$ & $0.19^{\mathrm{a}}$ & 0.009 & $<0.01$ \\
\hline Total & 97.80 & 98.31 & 98.85 & 98.87 & & \\
\hline \multicolumn{7}{|l|}{$\%$ Solids recovery } \\
\hline Cheese & $45.12^{\mathrm{b}}$ & $52.12^{\mathrm{a}}$ & $50.86^{\mathrm{a}}$ & $51.75^{\mathrm{a}}$ & 0.412 & $<0.0001$ \\
\hline Drain whey & $53.81^{\mathrm{a}}$ & $47.43^{\mathrm{b}}$ & $47.38^{\mathrm{b}}$ & $48.26^{\mathrm{b}}$ & 0.566 & $<0.0001$ \\
\hline Pressed whey & $0.23^{\mathrm{b}}$ & $0.26^{\mathrm{b}}$ & $0.26^{\mathrm{b}}$ & $0.34^{\mathrm{a}}$ & 0.016 & $<0.01$ \\
\hline Total & 99.16 & 99.81 & 98.50 & 100.35 & & \\
\hline$\%$ Drain whey $^{2}$ & $91.28^{\mathrm{a}}$ & $88.73^{\mathrm{b}}$ & $88.18^{\mathrm{b}}$ & $88.05^{\mathrm{b}}$ & 0.354 & $<0.0001$ \\
\hline$\%$ Pressed whey $^{2}$ & $0.38^{\mathrm{b}}$ & $0.44^{\mathrm{b}}$ & $0.47^{\mathrm{b}}$ & $0.61^{\mathrm{a}}$ & 0.029 & $<0.01$ \\
\hline
\end{tabular}

${ }^{\mathrm{a}, \mathrm{b}}$ Means within the same row not sharing a common superscript differ $(P<0.05)$.

${ }^{1} \mathrm{UFHT}=$ cheeses made from UF-fortified cheesemilks using a high renneting temperature of $32.2^{\circ} \mathrm{C}$; UFLT $=$ cheeses made from UF-fortified cheesemilks using a low renneting temperature of $28.3^{\circ} \mathrm{C}$; UFLTL $=$ cheeses made from UF-fortified cheesemilks using a low renneting temperature of $28.3^{\circ} \mathrm{C}$ and a longer cutting time of $5 \mathrm{~min}$.

${ }^{2}$ Amount of drain whey and press whey obtained from $100 \mathrm{~kg}$ of cheesemilk. 
$5)$. This reduction in yield for the UFLT cheeses could be due to the lower $(P<0.01)$ amount of fat recovered in the UFLT cheeses compared with the other 2 types of UF-fortified cheeses. For the UFLTL cheese, actual yield increased slightly when the coagulum was allowed to firm up for extra 5 min before cutting, probably because of the slightly higher fat recovered in the UFLTL cheese. The $R C$ values were calculated for control and UF fortified cheeses as described by GovindasamyLucey et al. (2006) and the values were 0.924 and 0.938 , respectively. Using the calculated $R C$ values and the experimentally determined (from this study) $R F$ values, the $R S$ values were calculated (Table 5). Using these $R F, R C$, and $R S$ values, Van Slyke cheese yield equations (Eq. [1]) were developed for all 4 cheeses (Table 5); these formulas predicted the experimentally obtained (actual) cheese yield (Table 5).

\section{Whey Composition}

The amount of total whey (including drain whey and press whey) produced during cheesemaking was lower when higher TS cheesemilks were used (Table 6). In cheeses made from control milks, the total amount of whey produced was approximately $92 \%$ of the original weight derived from the cheesemilk, but this value decreased to $89 \%$ for the 3 UF-fortified milks. True protein and total fat contents were significantly $(P<$ 0.01 ) higher in whey produced from milks that were fortified with UF retentates, whereas the lactose levels were lower. Total solid contents in whey derived from both control and UF-fortified milks were similar. Whey produced from higher TS milks had a lower proportion of lactose (65-66\%) and higher proportion of true protein $(12-13 \%)$ in the TS compared with control (69 and $10 \%$ of lactose and true protein in TS, respectively). This was due to the loss of lactose as well as the loss of NPN (in the permeate) during the UF process. Changing the coagulation conditions (decreasing the renneting temperature or increasing cutting time) did not have any effect on the composition of the whey, as wheys produced by UFHT, UFLT, and UFLTL processes had similar composition.

\section{Cheese Ripening and Grading}

Using higher TS milks, reducing renneting temperature, or increasing the cutting time for UF-fortified milks did not result in any significant difference in the formation of $12 \%$ TCA-soluble $\mathrm{N}$ during cheese ripening (Table 7, Figure 1). Because both starters and rennet were added to cheesemilks on a $\mathrm{CN}$ basis rather than by volume, the amount of $12 \%$ TCA-soluble $\mathrm{N}$ formed did not differ when higher TS milks were used. This is consistent with our previous work on the use of UF retentates to fortify cheesemilks for the manufacture of Parmesan and stirred-curd pizza cheese (GovindasamyLucey et al., 2004, 2005). When rennet is added on a milk volume basis, increasing the milk protein concentration results in slower rate of proteolysis in cheeses (Green et al., 1981; Green, 1985; Creamer et al., 1987; Spangler et al., 1990; Guinee et al., 1994). As expected, the amount of $12 \%$ TCA-soluble $\mathrm{N}$ increased with age (Table 7, Figure 1).

The $\mathrm{pH}$ values for all cheeses were similar during ripening (Table 7, Figure 2), irrespective of whether UF

Table 5. Actual and calculated cheese yield values for Swiss cheese $(n=4)$

\begin{tabular}{|c|c|c|c|c|c|c|}
\hline Item & \multicolumn{4}{|c|}{ Treatment $^{1}$} & SEM & $P$-value \\
\hline $\begin{array}{l}R F \text { value }^{2} \\
R S \text { value }^{3} \\
R C \text { value }^{4} \\
\text { Actual yield }^{5}(\%) \\
\text { Van Slyke cheese yield }{ }^{6}(\%) \text { using } R F, R C \text {, and } R S \text { values } \\
\text { Averaged moisture adjusted yield to } 38 \% \text { moisture }(\%)\end{array}$ & $\begin{array}{l}0.898 \\
1.081 \\
0.924 \\
8.49^{\mathrm{c}} \\
8.49^{\mathrm{c}} \\
8.02^{\mathrm{c}}\end{array}$ & $\begin{array}{r}0.896 \\
1.081 \\
0.938 \\
11.20^{\mathrm{a}} \\
11.21^{\mathrm{a}} \\
10.54^{\mathrm{a}}\end{array}$ & $\begin{array}{r}0.876 \\
1.069 \\
0.938 \\
10.99^{\mathrm{b}} \\
10.98^{\mathrm{b}} \\
10.30^{\mathrm{b}}\end{array}$ & $\begin{array}{r}0.889 \\
1.067 \\
0.938 \\
11.15^{\mathrm{a}} \\
11.16^{\mathrm{a}} \\
10.49^{\mathrm{a}}\end{array}$ & $\begin{array}{l}0.051 \\
0.049 \\
0.054\end{array}$ & $\begin{array}{l}<0.0001 \\
<0.0001 \\
<0.0001\end{array}$ \\
\hline \multicolumn{7}{|c|}{$\begin{array}{l}\mathrm{a}-\mathrm{c} \\
{ }^{2}\end{array}$} \\
\hline \multicolumn{7}{|c|}{$\begin{array}{l}{ }^{1} \mathrm{UFHT}=\text { cheeses made from UF-fortified cheesemilks using a high renneting temperature of } 32.2^{\circ} \mathrm{C} \text {; UFLT }=\text { cheeses made from UF-fortified } \\
\text { cheesemilks using a low renneting temperature of } 28.3^{\circ} \mathrm{C} \text {; UFLTL }=\text { cheeses made from UF-fortified cheesemilks using a low renneting tempera- } \\
\text { ture of } 28.3^{\circ} \mathrm{C} \text { and a longer cutting time of } 5 \text { min. } \\
{ }^{2} R F \text { is the fat recovered in cheese, determined experimentally from cheese trials. } \\
{ }^{3} R S \text { is the recovery of non-CN, nonfat solids in cheese. It was calculated as described in Govindasamy-Lucey et al. (2006). } \\
{ }^{4} R C \text { was calculated as described by Govindasamy-Lucey et al. (2006). The calculated RC values for UFHT, UFLT, and UFLTL cheeses were } \\
0.937 \text {, } 0.938 \text {, and } 0.940 \text {, respectively. Thus, all calculations were carried out using an average RC value of } 0.938 \text { for the UF-fortified cheeses. } \\
{ }^{5} \text { Actual yield determined experimentally from cheese trials was calculated for each vat of cheese as the weight of cheese divided by the weight of } \\
\text { the original cheese milk (including the amount of cultures added during cheese manufacture), multiplied by } 100 \text {. } \\
{ }^{6} \text { Van Slyke cheese vield was calculated using equation [1], using milk and cheese composition data given in Table } 2 .\end{array}$} \\
\hline
\end{tabular}


Table 6. Mean $(\mathrm{n}=4)$ lactose, true protein, TS, and fat composition in whey, normalized to concentrations that would be produced from 100 $\mathrm{kg}$ of standardized milk

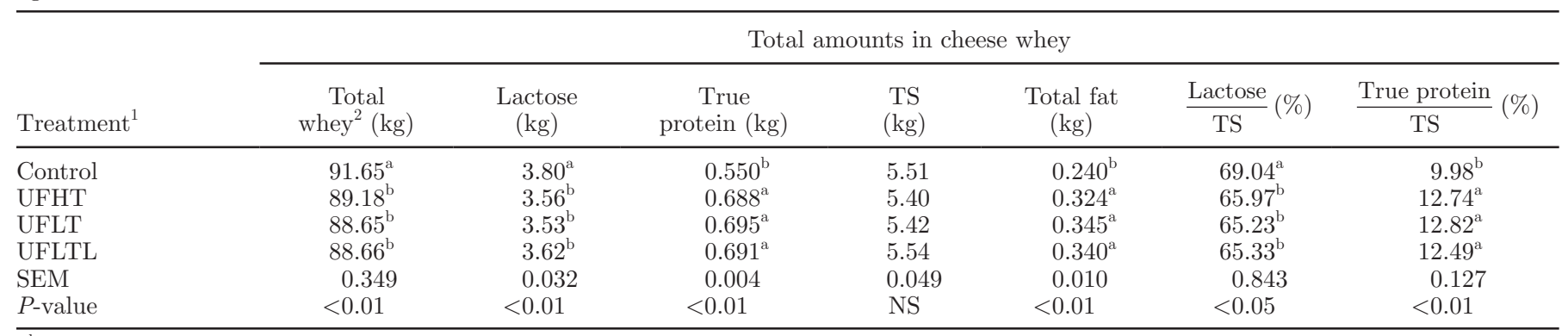

${ }^{\mathrm{a}, \mathrm{b}}$ Means within the same column not sharing a common superscript differ $(P<0.05)$.

${ }^{1} \mathrm{UFHT}=$ cheeses made from UF-fortified cheesemilks using a high renneting temperature of $32.2^{\circ} \mathrm{C}$; UFLT $=$ cheeses made from UF-fortified cheesemilks using a low renneting temperature of $28.3^{\circ} \mathrm{C}$; UFLTL $=$ cheeses made from UF-fortified cheesemilks using a low renneting temperature of $28.3^{\circ} \mathrm{C}$ and a longer cutting time of $5 \mathrm{~min}$.

${ }^{2}$ Total whey $($ after water addition) $=$ drain whey + press whey.

retentate, lower renneting temperature, or increased cutting times were used during the manufacture of Swiss cheese. Although UF-concentrated milks have higher buffering capacity because of the increased CN and colloidal calcium phosphate contents (Lucey and Fox, 1993), this did not affect $\mathrm{pH}$ development in our study, likely because the lactose contents in the serum phase of all cheesemilks were similar (Table 3). The $\mathrm{pH}$ values of cheeses at $1 \mathrm{~d}$ ranged from 5.1 to 5.3. By the end of $270 \mathrm{~d}$ of ripening, $\mathrm{pH}$ values had increased to 5.7 to 6.0. The $\mathrm{pH}$ of cheeses increased during ripening as lactic acid was consumed by the propionibacteria in the warm room to form propionic acid, acetic acid, and carbon dioxide (Steffen et al., 1993). A pH increase could also be due to the solubilization of colloidal calcium phosphate (Hassan et al., 2004).

The physical appearance of all the cheeses was good, and eye development was uniform throughout the cheeses. The quantity, size, and distribution of eyes formed in the cheeses did not differ among treatments. Sensory analysis by 2 experienced Swiss cheese graders at 4, 6, and 9 mo did not reveal any significant differences between the cheeses. No specific off-flavors were found in any of the cheeses.

\section{CONCLUSIONS}

Ultrafiltration retentates produced by processing at cold temperatures were successfully used to manufacture Swiss cheese. Interest is growing in the membrane filtration of milk at low temperatures because of the reduced risk of microbial growth during this processing procedure. Fortification of cheesemilk with UF retentates reduced both the gelation and cutting times because we had an increase in the substrate $(\mathrm{CN})$ and enzyme (rennet was added to cheesemilks on a $\mathrm{CN}$

Table 7. Mean squares, probabilities (in parentheses), and $\mathrm{R}^{2}$ for $\mathrm{pH}$ and $12 \%$ TCA-soluble $\mathrm{N}$ formed during ripening of Swiss cheese at $7^{\circ} \mathrm{C}$ for $270 \mathrm{~d}$

\begin{tabular}{|c|c|c|c|c|}
\hline Factor & df & $\mathrm{pH}$ & df & $\%$ Proteolysis \\
\hline \multicolumn{5}{|l|}{ Whole-plot } \\
\hline Treatment $(\mathrm{T})$ & 3 & $\begin{array}{c}0.003 \\
(0.86)\end{array}$ & 3 & $\begin{array}{c}5.580 \\
(0.25)\end{array}$ \\
\hline Day of cheesemaking (D) & 1 & $\begin{array}{c}0.414 \\
(<0.05)\end{array}$ & 1 & $\begin{array}{c}74.76 \\
(<0.05)\end{array}$ \\
\hline \multicolumn{4}{|l|}{ Subplot } & 2.398 \\
\hline Age $(\mathrm{A})$ & 1 & $\begin{array}{c}1.11 \\
(<0.001)\end{array}$ & 3 & $\begin{array}{l}486.72 \\
(<0.001)\end{array}$ \\
\hline $\mathrm{A} \times \mathrm{A}$ & 1 & $\begin{array}{c}0.272 \\
(<0.001)\end{array}$ & - & - \\
\hline $\mathrm{A} \times \mathrm{T}$ & 3 & $\begin{array}{c}0.001 \\
(0.99)\end{array}$ & 9 & $\begin{array}{c}0.533 \\
(0.93)\end{array}$ \\
\hline $\mathrm{A} \times \mathrm{A} \times \mathrm{T}$ & 3 & $\begin{array}{l}0.0004 \\
(1.00)\end{array}$ & - & - \\
\hline $\begin{array}{l}\text { Error } \\
\mathrm{R}^{2}\end{array}$ & 48 & $\begin{array}{l}0.034 \\
0.827\end{array}$ & 44 & $\begin{array}{l}1.348 \\
0.963\end{array}$ \\
\hline
\end{tabular}




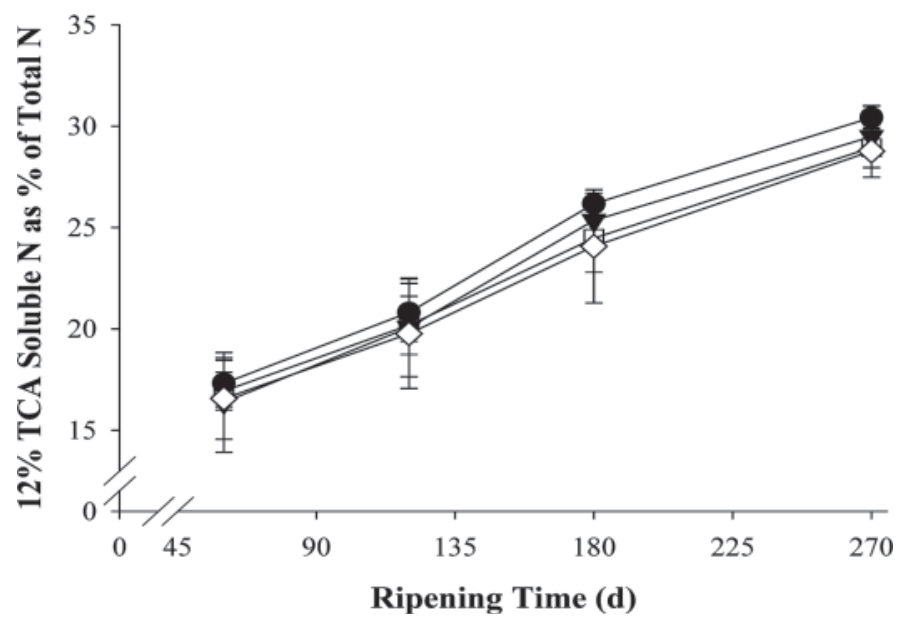

Figure 1. The $12 \%$ TCA-soluble $\mathrm{N}$ as a percentage of total $\mathrm{N}$ during ripening of Swiss cheeses at $7^{\circ} \mathrm{C}$ for control cheeses $(\mathbf{)})$, cheeses made from UF-fortified cheesemilks using high renneting temperature of $32.2^{\circ} \mathrm{C}(\boldsymbol{\nabla})$, cheeses made from UF-fortified cheesemilks using low renneting temperature of $28.3^{\circ} \mathrm{C}(\square)$, and cheeses made from UFfortified cheesemilks using a low renneting temperature of $28.3^{\circ} \mathrm{C}$ and a longer cutting time of $5 \mathrm{~min}(\diamond)$. Vertical bars represent standard deviations.

basis) in our experimental design. Decreasing the renneting temperature slowed the gelation process but resulted in greater fat losses, probably due to weaker CN interaction or less fusion of $\mathrm{CN}$ micelles in the network. Allowing more time for the weak network to strengthen before the initiation of cutting resulted in improved fat recovery. Higher $\mathrm{N}$ recovery was observed in cheeses made from UF-fortified milks because these cheesemilks had a greater proportion of CN to total protein. When

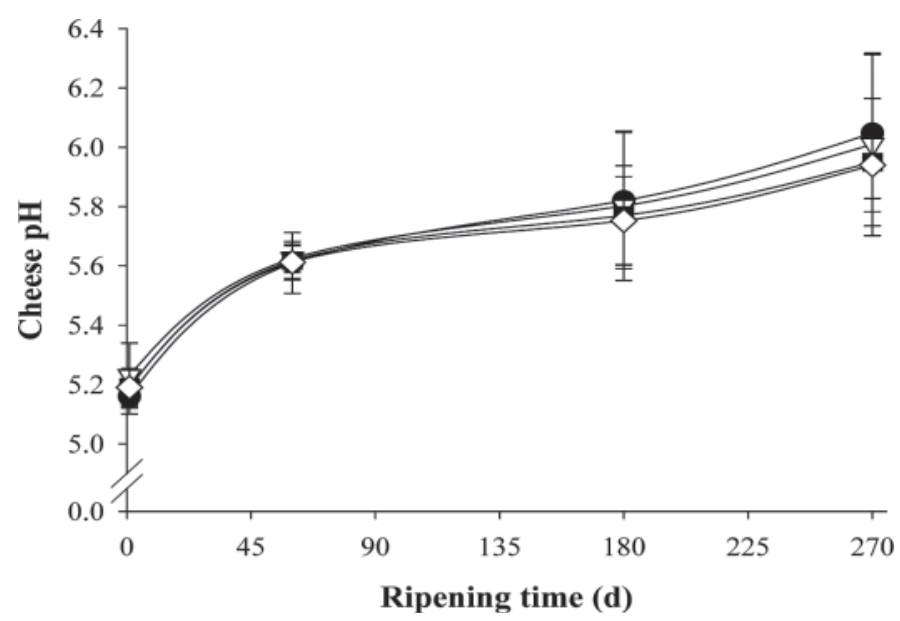

Figure 2. $\mathrm{pH}$ values during the ripening of Swiss cheeses at $7^{\circ} \mathrm{C}$ for control cheeses $(\mathbf{)})$, cheeses made from UF-fortified cheesemilks using high renneting temperature of $32.2^{\circ} \mathrm{C}(\nabla)$, cheeses made from UFfortified cheesemilks using low renneting temperature of $28.3^{\circ} \mathrm{C}(\boldsymbol{\square})$, and cheeses made from UF-fortified cheesemilks using a low renneting temperature of $28.3^{\circ} \mathrm{C}$ and a longer cutting time of $5 \mathrm{~min}(\diamond)$. Vertical bars represent standard deviations.
UF retentates are used to fortify Swiss cheesemilks, the coagulation conditions should be adjusted (e.g., using a lower renneting temperature or allowing the coagulum to become firmer before cutting). Proteolysis was similar in all cheeses, suggesting that fortification with UF retentates should not alter cheese ripening if starter and rennet are equivalent. We conclude that standardization of milk with cold UF retentates up to $3.3 \% \mathrm{CN}$ (13.4\% TS) could be used to successfully produce Swiss cheese with increased yield without impairing quality attributes.

\section{ACKNOWLEDGMENTS}

The authors thank the following Wisconsin Center for Dairy Research and University of WisconsinMadison Dairy Plant (Madison, WI) personnel for their assistance and support in membrane processing, milk processing, cheesemaking, and analytical work: Bill Hoesly, the late Brian Leitzke, Bill Tricomi, Amy Bostley, Kristen Houck, Cathy Landers, Juan Romero, Gene Barmore, Karen Smith, Ray Michaels, Ken Norton, Gina Mode, and Bill Klein. We also thank Robert Fassbender from T. C. Jacoby (St. Louis, MO), and personnel from Membrane Systems Specialists (Wisconsin Rapids, WI) for their assistance in setting up the UF units. We thank Jongwoo Choi (Department of Food Science, University of Wisconsin-Madison) for his help with the statistical analysis of the data. We also thank Chr. Hansen Inc. (Milwaukee, WI), Cargill Texturizing Solutions (Waukesha, WI), and Danisco USA Inc. (Madison, WI) for their donation of starter cultures and coagulants used in this study. The financial support of the Wisconsin Center for Dairy Research Cheese Industry Team, Wisconsin Milk Marketing Board (Madison, WI), and Dairy Management Inc., as administered by Dairy Research Institute (Rosemont, IL), is greatly appreciated.

\section{REFERENCES}

Association of Official Analytical Chemists. 2000. Official Methods for Analysis. 17th ed. AOAC, Arlington, VA.

Boehringer Mannheim. 1997. UV method for the determination of lactose and D-galactose in food stuffs and other materials. RBiopharm, test kit catalog \# 10176303 035. Boehringer Mannheim, Mannheim, Germany.

CFR (Code of Federal Regulations). 2005. 21CFR133.113-114, 133.155-156: Cheese and related food products. http://edocket. access.gpo.gov/cfr_2002/aprqtr/21cfr133.113.htm.

Creamer, L. K., M. Iyer, and J. Lelievre. 1987. Effect of various levels of rennet addition on characteristics of Cheddar cheese made from ultrafiltered milk. N.Z. J. Dairy Sci. Technol. 22:205-214.

Dalgleish, D. G. 1982. The enzymatic coagulation of milks. Pages 157187 in Developments in Dairy Chemistry. Vol. 1: Proteins. P. F. Fox, ed. Elsevier Applied Science, London, UK.

Dikkeboom, A. 1999. Lower fat Swiss cheese-Can we improve the flavor? Dairy Pipeline 11:4-5,8-9. Wis. Center for Dairy Res, Madison. 
Dudley, E. G., and J. L. Steele. 2005. Succinate production and citrate catabolism by Cheddar cheese nonstarter lactobacilli. J. Appl. Microbiol. 98:14-23.

Fassbender, R. 2001. Using cold ultrafiltered milk in cheesemaking. In Proc. Marschall Cheese seminar. Accessed Mar. 19, 2011. http:// www.fda.gov/ohrms/DOCKETS/dockets/00p0586/00p-0586bkg0001-51-Ref-49-Fassbender-vol25.pdf.

Govindasamy-Lucey, S., J. J. Jaeggi, A. L. Bostley, M. E. Johnson, and J. A. Lucey. 2004. Standardization of milk using cold ultrafiltration retentates for the manufacture of Parmesan cheese. J. Dairy Sci. 87:2789-2799.

Govindasamy-Lucey, S., J. J. Jaeggi, M. E. Johnson, T. Wang, and J. A. Lucey. 2005. Use of cold ultrafiltered retentates for standardization of milks for pizza cheese: Impact on yield and functionality. Int. Dairy J. 15:941-955.

Govindasamy-Lucey, S., T. Lin, J. J. Jaeggi, M. E. Johnson, and J. A. Lucey. 2006. Influence of condensed sweet cream buttermilk on the manufacture, yield and functionality of pizza cheese. J. Dairy Sci. 89:454-467.

Green, M. L. 1985. Effect of pretreatment and making conditions on the properties of Cheddar cheese from milk concentrated by ultrafiltration. J. Dairy Res. 52:555-564.

Green, M. L. 1987. Effect of manipulation of milk composition and curd-forming conditions on the formation, structure and properties of milk curd. J. Dairy Res. 54:303-313.

Green, M. L., F. A. Glover, E. M. W. Scurlock, R. J. Marshall, and D. S. Hatfield. 1981. Effect of use of milk concentrated by ultrafiltration on the manufacture and ripening of Cheddar cheese. J. Dairy Res. 48:333-341.

Green, M. L., R. J. Marshall, and F. A. Glover. 1983. Influence of homogenization of concentrated milks on the structure and properties of rennet curds. J. Dairy Res. 50:341-348.

Green, W. C., and K. K. Park. 1980. Comparison of AOAC, microwave and vacuum oven methods for determining total solids in milk. J. Food Prot. 43:728-783.

Guinee, T. P., P. D. Pudja, and E. O. Mulholland. 1994. Effect of milk protein standardization, by ultrafiltration, on the manufacture, composition and maturation of Cheddar cheese. J. Dairy Res. 61:117-131.

Hassan, A., M. E. Johnson, and J. A. Lucey. 2004. Changes in the proportions of soluble and insoluble calcium during the ripening of Cheddar cheese. J. Dairy Sci. 87:854-862.

Johnson, M. E., C. M. Chen, and J. J. Jaeggi. 2001. Effect of rennet coagulation times on composition, yield, and quality of reduced-fat Cheddar cheese. J. Dairy Sci. 84:1027-1033.
Johnson, M. E., and N. F. Olson. 1985. A comparison of available methods for determining salt levels in cheese. J. Dairy Sci. 68:1020-1024.

Lucey, J. A. 2002. Formation and physical properties of milk protein gels. J. Dairy Sci. 85:281-294

Lucey, J. A., and P. F. Fox. 1993. Importance of calcium and phosphate in cheese manufacture: A review. J. Dairy Sci. 76:1714-1724.

Lucey, J. A., and J. Kelly. 1994. Cheese yield. J. Soc. Dairy Technol. $47: 1-14$.

Lucey, J. A., C. T. Teo, P. A. Munro, and H. Singh. 1997a. Rheological properties at small (dynamic) and large (yield) deformations of acid gels made from heated milk. J. Dairy Res. 64:591-600.

Lucey, J. A., T. van Vliet, K. Grolle, T. Geurts, and P. Walstra. 1997b. Properties of acid casein gels made by acidification with glucono- $\delta$ lactone. 1. Rheological properties. Int. Dairy J. 7:381-388.

Marshall, R. T., ed. 1992 Standard Methods for the Examination of Dairy Products. 16th ed. Am. Publ. Health Assoc. Inc., Washington, DC.

Mishra, R., S. Govindasamy-Lucey, and J. A. Lucey. 2005. Rheological properties of rennet-induced gels during the coagulation and cutting process: Impact on processing conditions. J. Texture Stud. $36: 190-212$

SAS Institute. 2002-2003. SAS User's Guide: Statistics. Version 9.1. SAS Inst., Inc., Cary, NC.

Spangler, P. L., L. A. Jensen, C. H. Amundson, N. F. Olson, and C. G. Hill. 1990. Gouda cheese made from ultrafiltered milk: Effects of concentration factor, rennet concentration and coagulation temperature. J. Dairy Sci. 73:1420-1428.

Steffen, C., P. Eberhard, J. O. Bosset, and M. Ruegg. 1993. Swisstype varieties. Pages $83-110$ in Cheese: Chemistry, Physics and Microbiology. Vol. 2. P. F. Fox, ed. Chapman \& Hall, London, UK.

Sutherland, B. J., and G. W. Jameson. 1981. Composition of hard cheese manufactured by ultrafiltration. Aust. J. Dairy Technol $36: 136-143$

Van Slyke, L. L., and W. V. Price. 1936. Cheese. Orange Judd Publ. Co. Inc., New York, NY.

Walstra, P. 1993. The syneresis of curd. Pages. 141-191 in Cheese: Chemistry, Physics and Microbiology. Vol. 1. General Aspects. P. F. Fox, ed. Chapman \& Hall, London, UK.

Zoon, P., T. van Vliet, and P. Walstra. 1988. Rheological properties of rennet-induced skim milk gels. 1. Introduction. Neth. Milk Dairy J. $42: 249-269$. 